\title{
Suffrage Expansion and Legislative Behavior in Nineteenth-Century Britain
}

GARY W. COX \& JAMES W. INGRAM III

THE IMPORTANCE OF SUFFRAGE expansion to the formation of "modern" political parties - and with them mass representative democracy as we know it today-is widely recognized. Nonetheless, most of what we know about the link between suffrage expansion and democratic politics concerns only the electoral arena. The major comparative studies of party development (Weber I946; Duverger 1955; LaPalombara and Weiner 1966), for example, have stressed how larger electorates led to more elaborate and centralized extra-parliamentary organization, to "populist" campaigning styles, and to the promotion of socialist parties. 'This study concerns the legislative effects of extending the suffrage. Although we focus on nineteenth-century Britain, parts of our argument pertain to other cases.

The Reform Acts of 1832, 1867, and I884, by which the British electorate was expanded, have been the most widely recog-

Gary W. Cox is professor of political science at the University of California at San Diego. He is the author of The Efficient Secret: The Cabinet and the Development of Political Parties in Victorian England (1987) and of "The Origin of Whip Votes in the House of Commons" (forthcoming in Parliamentary History). His research here was supported by the National Science Foundation under grant SES-88I1022.

James W. Ingram III is a doctoral candidate in political science at the University of California at San Diego. He is currently doing research on the electoral politics of charter reform in Los Angeles.

Social Science History 16:4 (Winter 1992). Copyright (C) 1992 by the Social Science History Association. CCC 0I45-5532/92/\$1.50. 
nized landmarks of nineteenth-century British political history. By greatly extending the suffrage, lessening malapportionment, and converting most of the country to single-member rather than double-member districts, the acts profoundly influenced the conduct of elections. Electoral changes, in turn, led to changes in the behavior of MPs in the House of Commons. Contemporaries noted, for example, that members were more prolix after the first reform act than before in an effort to get their names in the newspapers. ${ }^{2}$

Surprisingly little systematic research has been done, however, on how active the typical MP was, and in what ways, before and after reform. Not even the most basic statistics on backbench legislative activity, for example, such as the number of bills introduced and passed by private members, have been compiled for the nineteenth century, except for a few brief periods (Ilbert I90I, 215; Fraser 1960, 455 n. 2; Richards 1979, 300; Ramm 1984, 744) ${ }^{3}$ Similarly, although Chester and Bowring's statistical appendix tells us how many questions were asked in aggregate (at least after I873), it does not tell us what kind of member was asking them.

In this study we attempt to fill a part of the gap in our knowledge of backbench activity, especially as that activity relates to private members' bills. In section I we explain why one ought to expect greater legislative activity by private members. Section 2 presents statistics on the number and subsequent success of bills introduced by backbenchers and frontbenchers. The percentage of private members' bills enacted declined sharply just after passage of the second and third reform acts and in the decade before passage of the first reform act. The decline in backbench success rates after the second and third reform acts is concomitant with a large increase in the number of bills introduced by private members. Larger constituencies led to more active MPs; but these MPs had no better, and sometimes worse, opportunities than their predecessors to push bills through Parliament-hence, the number of successful backbench bills changed little, while the percentage declined considerably. Section 3 complements the longitudinal study undertaken in section 2 with a cross-sectional examination of backbench activity. Section 4 discusses some of the legislative consequences of the declining ability of individual backbench- 
ers to steer legislation through the various parliamentary shoals. Section 5 offers our conclusions.

\section{ELECTORAL AND LEGISLATIVE POLITICS}

In this section we will outline some reasons for expecting that each reform act should have stimulated legislative activity. We begin simply by recalling the three acts' basic elements. Each reform changed voting requirements to increase the number of citizens eligible to vote in parliamentary elections - the first (I832) by $50 \%$ to $80 \%$, the second ( 1867 ) by almost $100 \%$, the third (I884) by about $75 \%$ - and each reform redrew the boundaries of parliamentary districts to lessen malapportionment. ${ }^{4}$ Thus, the size distribution of constituencies was shifted upward: tiny constituencies disappeared, then small ones, and, after 1885 , only mass constituencies remained.

Moreover, each reform act was followed, not just by an increased number of large constituencies, but by a considerably increased number of contested ones. Where only $27 \%$ of English constituencies were contested on average at the five general elections from 1812 through 1830 , this figure jumped to $59 \%$ for the nine elections held after 1832 , to $80 \%$ after 1867 , and to $86 \%$ after $1885 .^{5}$

MPs who faced larger, more competitive constituencies had greater electoral incentives to be active in seeking legislative solutions to social and economic problems. The optimal electoral strategy for those MPs sitting for small provincial boroughs was to engage in traditional personal and particularistic politics; they could introduce bills to deal with problems of the industrial revolution if they wished, but there was little specifically electoral pressure to do so. In contrast, MPs for the larger boroughs faced, not just constituents too numerous to visit individually, but constituents vitally concerned with the problems of an expanding society. ${ }^{6}$

The accuracy of these remarks is suggested by the ratcheting up of the number of MPs participating in debate after each reform act. In the unreformed House, the percentage of MPs who debated in the typical session ranged from $30 \%$ to $37 \%$. After the first, second, and third reform acts, the comparable ranges were from $45 \%$ 
to $64 \%$, from $67 \%$ to $70 \%$, and from $80 \%$ to $90 \%$, respectively (Glynn 1949: 206; Cox 1987: 53). The size and competitiveness of the constituencies seem clearly to have played an important role in stimulating backbench prolixity.

This line of thought suggests that reform should have had a predictable syndrome of effects as regards bills: after an extension of the suffrage, more MPs would come from reasonably sized and competitive constituencies, hence more would have-above and beyond any personal motivation-an electoral motivation to be active; if no more time were allocated in aggregate to private members interested in enacting bills, yet more sought to use what time there was, the percentage of private members' bills passed would necessarily decline. The next section provides a more systematic assessment of whether the reform acts did have an impact along these lines.

\section{PRIVATE MEMBERS' BILLS}

Bills in the House of Commons come in two kinds: public and private. The former deal with matters of general or national concern, the latter with matters of personal or local concern. Because the procedure used to consider private bills has been quasijudicial since 1855 ( 1844 for railway bills), and because the government virtually never involved itself in private bill controversies even before this procedural change, we have confined our attention to public legislation.

Since early in the nineteenth century, public legislation has been classified as either government bills or private members' bills. The distinction is based on whether a government member or a private member moved for leave to introduce the bill. ${ }^{7}$ By tracking down each public bill listed in selected volumes of the Commons' Journal from I8I 4 to 1899 , we have verified the number of bills introduced and enacted by both government and private members. ${ }^{8}$

\section{The Number of Private Members' Bills Introduced}

We shall first ask whether the figures compiled reveal a ratcheting up in the number of private members' bills introduced after each reform act, as the argument of the previous section suggests. The answer depends on which reform act is being talked about. 


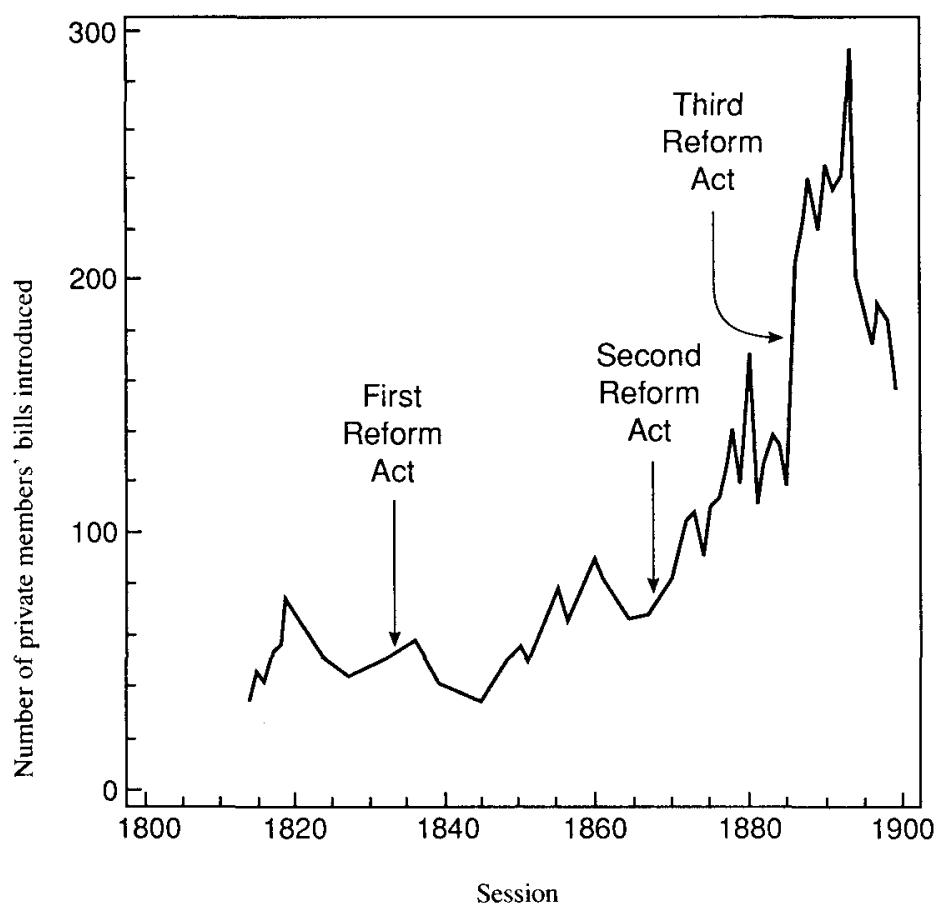

Figure I Number of private members' bills introduced, I8I4-I899

A ratcheting up is clearly evident after the third reform act. In the late 1870 s and early I 880 os private members introduced an average of 132 bills per session, with little if any trend. In the first Parliament elected under the terms of the new reform act, the number jumped to 205 , and the average thereafter was even higher, about 214 (see Figure 1).

The situation is less clear in the case of the second reform act. Although the number of bills introduced increases from 69 in the last Parliament elected under the terms of the first reform act to 79 in the first elected under the terms of the second, the increase is not large and the figures do not level off, either before or after the reform. A slight upward trend occurs in the number of bills introduced by private initiative starting in the mid- $1840 \mathrm{os}$, and the trend continues through the first few years of the second Disraeli ministry. Nonetheless, the average number of private members' 
bills from I $836-67$ was only 62 , while the comparable figure from $1869-84$ was nearly double that, at $116 .{ }^{9}$

The legislative response is weakest in the case of the first reform act. Although Sir Robert Peel complained that "there was a great appetite for legislation" in the reformed Parliament and "a strong desire among hon. Members to be distinguished as the introducers of new laws," 10 the numbers do not show any great increase in backbench legislative activity. If one compares the entire pre-reform period to the entire period between the first and second reform acts, there was an increase-5I private members' bills per session in the earlier period, versus 62 in the later period. But this increase is not statistically significant ( $t$ of 1.9 ) and there was no immediate increase in backbench legislative activity on passage of the act. This finding jibes with Gash's (1977) general emphasis on the continuities between the pre-reform and postreform periods. Apparently the first reform act was not as significant in terms of stimulating the introduction of private members' bills as were the later reforms.

\section{Explaining the First Reform Act's Lack of Effect}

The explanation for the difference between the first and later reform acts may have to do with the nature of the constituencies and of parliamentary procedure. Although the 1832 reform act did abolish tiny constituencies- those with fewer than a hundred electors-it nonetheless left a substantial proportion of small ones. Among English boroughs, for example, nearly $40 \%$ had fewer than 500 electors in 1833 , and nearly two-thirds had fewer than a thousand electors. Mass constituencies, in which it was impossible for the MP to know all of his voting constituents, arrived mostly with the second and especially the third reform acts. Probably one should have expected that the transition from tiny to small would stimulate less legislative activity than the transition from small to medium-sized and mass.

Perhaps more important, backbenchers earlier in the century had a wider variety of options than did their successors. The private member in the early Victorian period had many ways to achieve his ends other than introducing bills. This was not true in every case, of course. Some members who introduced bills wished 
personally to push them through to passage. For them, there really was no substitute for introducing their bills to begin with. Other members, however-and they probably constituted a substantial majority-introduced bills to prod the government into action, to publicize causes, or to demonstrate zeal to their constituents. Such purposes required only that the member seize some portion of legislative time and state his views, and this could be done in a variety of ways: by presenting a petition (until I835), by moving an amendment to the motion that a particular Order of the Day be taken up (until I 837), by moving an amendment to the motion that the Orders of the Day be read (until 1848), by raising a debate on Friday adjournment (until I86I), by moving an amendment on going into Committee of Supply, and so forth.

Indeed, the substitutability of different methods for seizing a bit of legislative time can be seen throughout nineteenth-century procedural history. One finds contemporary MPs clear on this score. For example, in a series of debates on procedure in the early 1870 s, four separate speakers discoursed on the origin and history of various forms of the House, in each case illustrating how private members who were denied one device would substitute another. One member focused on the origin of the practice of making motions upon going into Committee of Supply, noting that it came about as a response to the removal of a previous right:

Motions on going into Committee of Supply were not to be met with earlier than $\mathrm{I} 8 \mathrm{I}$ I, when Parliament cancelled a rule, which had always been maintained up to that time. . . . Mr. Thomas Creevey, being aggrieved, made a motion in going into Committee of Supply, and that was the origin of the practice... (Debates ccix, I059).

The same MP noted that the use of motions upon going into Supply was relatively limited in the early years: there were only three in the first decade after its invention. A later speaker in the same debate described how such motions first came into common use:

Before the year 1835 , it was the habit of hon. Members on presenting Petitions to make statements with respect to them. . . . Owing to the time which it took up, however, the practice was abolished by the common consent of the House; but the result was what might have been expected: when hon. 
Members were deprived of one opportunity of bringing forward questions of interest to themselves and their constituents under one particular form of the House, they would be sure to invent another, so in this case, they embraced the opportunity of bringing forward questions on going into Committee of Supply . . . (Debates ccix, 1076).

A year later, the government introduced a resolution that sought to curtail the use of motions upon going into Supply. One MP, speaking against the government's proposal, asked rhetorically whether it really could shut off the flow of talk from the back benches:

The infallible result would be that private Members would act as they did last year. Take his own case as an example. Finding it was impossible to bring forward his Motion, he discovered a plan of saying in the discussion of the Estimates everything he wanted to say. . . . He gave Notice that he would move a reduction of the salary of the Secretary of State for War by $£ 2,000$ a year . . (Debates ccxiv, 263-64).

Another MP, speaking in the session after the government's proposals had been passed, noted a consequence-not an increase in motions to reduce the salaries of secretaries of state, as had been predicted, but an increase in the introduction of bills:

I have observed that, since the adoption of the restrictions which recent standing orders have placed on the opportunities for moving Amendments in Supply, the tendency of hon. Members has been to multiply the number of Bills before the House; and I feel convinced, when I see a notice for the second reading of some Bills given at the end of February for the I6th of July following, that that Bill stands there without any hope whatever, on the part of the hon. Member who introduced it, that it can pass into law, but that he merely means to treat it as . . . a kind of peg upon which to hang a statement or declamation (Debates ccxv, 234).

What is suggested by this digression, then, is that MPs in the I 830 s had a wider variety of techniques for securing the attention of the House than did their successors. When the first reform act was passed and more MPs had electoral reasons to be active, there was indeed an immediate increase in backbench activity: more 
speaking in debate, more presenting of petitions, more asking of questions, more moving of amendments on going into Committee of Supply, more moving of amendments to the Orders of the Day, more raising of adjournment debates. There was no increase in the number of bills introduced because these other, more flexible, methods of seizing attention were available. As these methods were abolished (on which, see Fraser 1960; Cox 1987), however, private members were increasingly restricted to a few main forms: introducing bills, making motions upon going into Committee of Supply, and asking questions. Thus, when the second and third reform acts were passed, and an influx of MPs serving larger and larger constituencies came into the Commons, a sizable and rather abrupt increase occurred in the number of backbench bills."

\section{A Secular Increase?}

Looking at the graph in Figure I, one may consider an alternative hypothesis: there was no ratcheting increase, but rather a longterm increase in backbench legislative activity. This presumably is what one would expect on the assumption that economic and social developments were the primary causes of increased legislationand there is some support for this notion from the mid-I840s to the mid-1870s. But after and before that 30-year period, there does not seem to be any secular increase. Moreover, if one asks whether a model that posits onetime increases after each reform act does better than one that posits a general secular increase, the answer is yes.

This can be seen by running a few simple regressions. First, to test a model that posits a long-term, linear increase, we regressed the number of private members' bills in each session on a constant term and a trend term. The results showed a statistically significant time trend and an adjusted $R^{2}$ of .64 . Next, to test a model that posits onetime increases after each reform act, we regressed the same dependent variable on a constant term and three dummy variables-one for each reform act. ${ }^{12}$ The results showed significant coefficients for the second and third reform act dummies and a somewhat larger adjusted $\mathrm{R}^{2}$ of .87 . Finally, to pit the two models against one another, we included both the time trend and the three reform act dummy variables in the same model. We 
found significant coefficients for the second and third reform act dummies, insignificant coefficients for the first reform act dummy and for the time trend. There is thus some statistical support for saying that the data in Figure I conform better to a ratcheting up model than to a long-term linear increase model.

\section{The Success of Backbench Bills}

All in all, the evidence from the previous sections is fairly clear. When there were substantial increases in the electorate-hence in the number of MPs facing "large" constituencies-the number of bills introduced by backbenchers increased. When more bills were introduced, however, it was almost guaranteed that a lower percentage would be successfully enacted. The time available for private members' bills to proceed through the House was limited. The reform acts themselves did nothing to improve the situation in the House; they did not, for example, allocate more time to backbenchers, or remove superfluous legislative steps, or introduce timesaving devices. Nor were improvements introduced thereafter; indeed, the general trend was for less time to be allocated to backbenchers. Hence, the result-at least for the second and third reform acts-was that about the same number of private members' bills were passed, even though many more were introduced, leading to a decline in the percentage passed.

Figure 2 displays the proportion of private members' bills enacted from I8I 4 to 1899 . The results, once again, are most striking for the third reform act: there is an immediate drop in the success rate of backbench bills, and the highest postreform rate is scarcely higher than the lowest pre-reform rate. The reform clearly introduced a "new era" in terms of backbench legislative success rates.

The results for the second reform act are only a little less striking. It is true that the drop in the percentage of private members' bills enacted does not occur immediately; there is a lag of two sessions before the decline. But when the drop comes, it is substantial and permanent: the average success rate is almost halved; and the highest post -1870 rate barely exceeds the lowest pre- 1870 rate. ${ }^{13}$

The results for the first reform act again fail to fit into the pattern observed for the later acts; the decline in backbench success rates comes before the reform, not after. Indeed, there is a recovery 


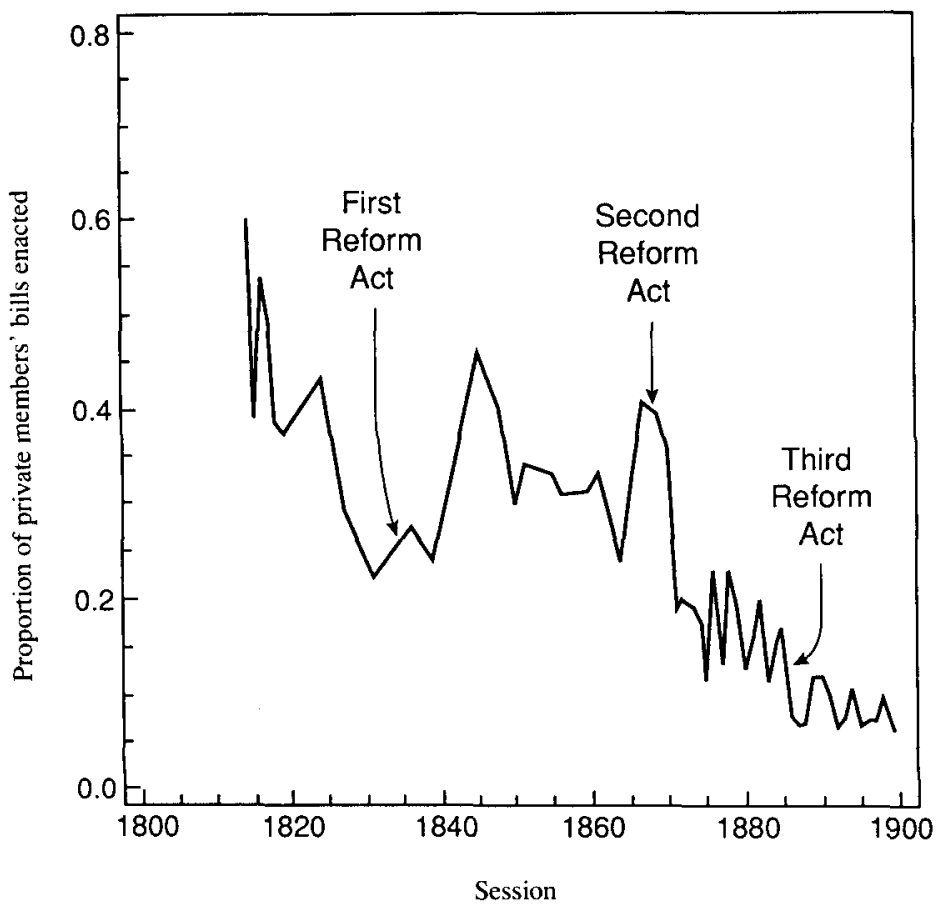

Figure 2 Proportion of private members' bills enacted, I8 I4-I899

about a decade after passage with the accession to power of the Peel Ministry in I84I.

As with Figure I, the graph in Figure 2 can be scrutinized for evidence of a long-term or secular trend (in this case downward), as might be expected on the hypothesis that general economic and social developments were the driving forces. In this case there is support for both the notion of a long-term linear decline and of onetime shifts at the second and third reform acts. If one regresses the percentage of private members' bills enacted in each session on a constant term, a trend term, and two dummy variables-one each for the second and third reform acts-one finds that the trend term and the two dummy variables are of the expected (negative) sign and statistically significant. ${ }^{14}$ If one excludes the first three sessions $(1814,1815$, and 1816$)$ from the analysis, the time trend is 
no longer statistically significant, while both reform act dummies remain significant.

\section{Backbenchers' Acts}

A final question concerns the percentage of acts introduced as private members' bills. The first point to make is that no systematic trend is evident in the number of acts that originated as government bills or as private members' bills (see Figure 3 ). The number of "government acts" fluctuates around an average of 82.5 per session with little trend (an insignificant slope of .007 in a regression on time), while the number of "private members' acts" fluctuates around an average of 20.2 with equally little trend (an insignificant slope of -.010)..$^{15}$ Thus, it is not surprising that no trend is found in the percentage of acts that originated as private members' bills: this percentage fluctuates without trend around an average slightly under 20.

The lesson of these figures is not that the private member maintained his presence in the statute books unimpaired. The importance of the acts passed on private initiative diminished, by all accounts, throughout the century, while the size and importance of the acts passed on government initiative grew. ${ }^{16}$ Thus, were the size and importance of acts taken into account, as well as their number, a downward trend would be evident in the relative importance of backbench acts.

This decline in the relative importance of backbench acts is part of the widely recognized "decline" of the private member. So too is the decrease in the percentage of backbench bills that were enacted. For, as the chances of legislative success for an individual backbencher got worse and worse, his prospects as an independent policy entrepreneur became poorer and poorer. These worsening prospects naturally led backbenchers to invent new procedures and abuse old ones, which caused no end of trouble to government after government. But the corporate position of backbenchers was not improved by these essentially individual and unorganized fiddlings with procedure. And the chief object of the ambitious backbencher increasingly became, not beating the gang of official members whose position looked so enviable, but joining them. Those who were left on the back benches could no longer exercise an independent initiative in matters legislative, and their 


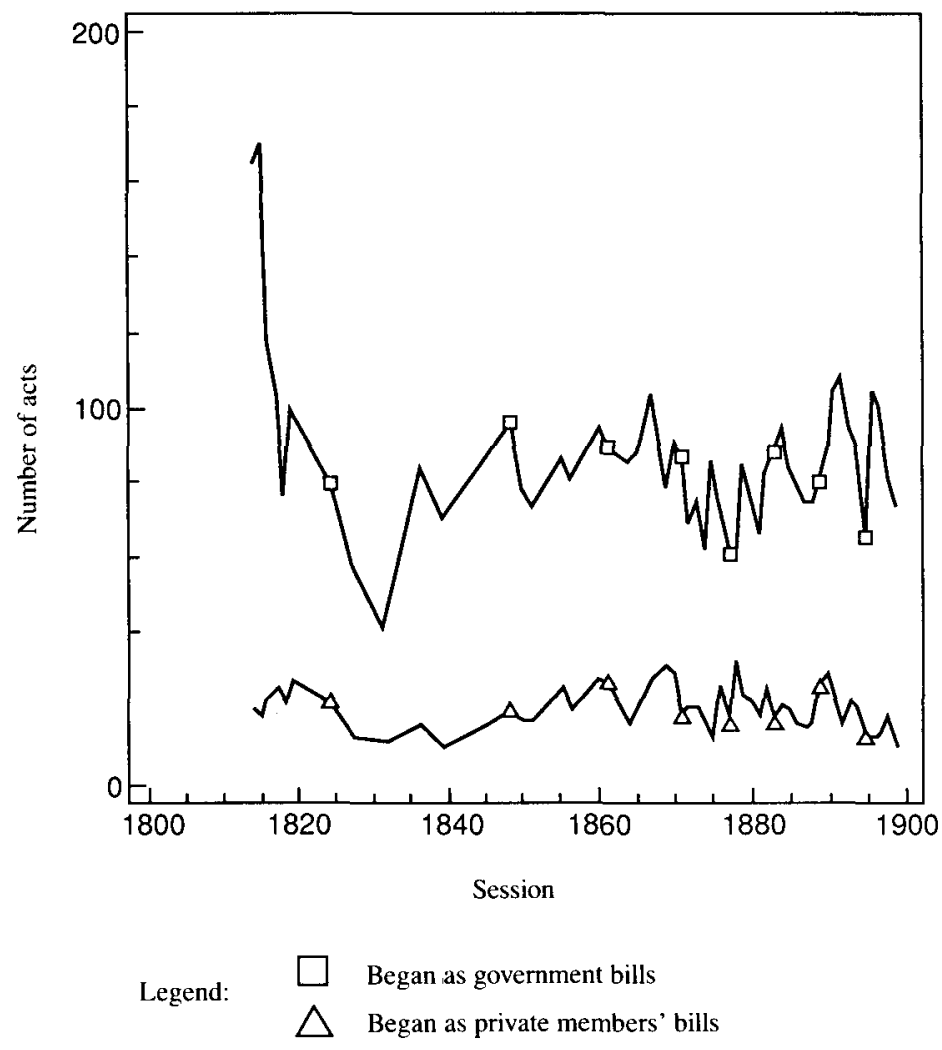

Figure 3 Number of acts which began as government and as private members' bills, I 8 I4-1899

role became more that of an internal lobbyist of frontbenchers in their own party than of an independent agent in the legislative process.

\section{MASS ELECTORAL POLITICS}

Thus far we have marshaled only longitudinal evidence in favor of the hypothesis that the reform acts had an indirect impact on MPs' behavior in the House of Commons. But the argument leading to this prediction-that MPs from larger constituencies faced greater 
electoral incentives to be active than did their colleagues from smaller places-also has clear cross-sectional implications. If the argument is valid, one ought to find at any given time that MPs from larger constituencies were more active; they talked more in debate, voted more in divisions, made more motions, introduced more bills, and so forth.

We note first some evidence that MPs from larger constituencies participated more frequently in debate. Cox $(1987,58)$ finds, for example, that in I835 MPs from large boroughs were about twice as likely to speak in debate as were MPs from small boroughs; in I859 they were half again as likely to speak. The differences between smaller and larger counties were smaller but in the expected direction. ${ }^{17}$

Similar evidence exists regarding participation in divisions. In both the Parliaments of $184 \mathrm{I}-47$ and $\mathrm{I} 852-57$, MPs from larger boroughs were more likely to vote than were their colleagues from smaller boroughs, and the same was true for counties (Cox 1987: 58-59).

More directly pertinent, there is evidence that MPs from larger constituencies introduced more bills. In I856, I 9 backbench MPs from English boroughs introduced bills. The average size of these I9 MPs' boroughs was almost twice the average of all English boroughs. Moreover, four of the 19 , or $21 \%$, came from boroughs with more than 5,000 electors, whereas only $6 \%$ of all English boroughs were that large. Thus, MPs from the larger boroughs were clearly overrepresented among the introducers of bills, at least in $1856 .{ }^{18}$

Finally, we note some more extensive evidence regarding the asking of questions. For each ministry from I832-67, Ingram (1990) has investigated the number of questions asked by each constituency's MP(s) by perusing randomly chosen portions of Hansard's from each ministry's tenure of office, keeping track of all questions asked during the selected periods. The end product is an accounting for each constituency and each ministry of the number of questions asked by MPs serving the constituency during a selected subperiod of the ministry. Thus, for example, no questions were asked by MPs serving the borough of Barnstaple during the portion of the Melbourne ministry of I835-4I that was searched; two questions were asked by MPs serving the borough of Tower Hamlets during the same period; and so forth. 
Table I Percentage of boroughs whose MP(s) asked questions, by size of borough

\begin{tabular}{lcc}
$\begin{array}{l}\text { Number of electors } \\
\text { in borough }\end{array}$ & $\begin{array}{c}\text { Average \% of boroughs } \\
\text { whose MP(s) asked questions }\end{array}$ & $\begin{array}{c}\text { Number of boroughs } \\
\text { of given size }\end{array}$ \\
\hline O-I , OOO & 18 & I3I \\
I, OOO-2,000 & 22 & 42 \\
$2,000-5,000$ & 35 & 18 \\
$5,000-10,000$ & 43 & 8 \\
I0,000- & 68 & 5 \\
\hline
\end{tabular}

Source: Author's compilation from Hansard.

Notes: The unit of observation is an English/Welsh borough during a particular ministry. If there were only one ministry, the $18 \%$ figure in the first row would mean that $18 \%$ of the English/Welsh boroughs with electorates less than $\mathrm{I}, 000$ were represented by MP(s) who asked at least one question during the subperiods of the ministry searched. Because there are actually ten ministries included in the analysis, the figure is just the simple average of the separate ministry figures. The subperiods of each ministry chosen for investigation were chosen at random and altogether constituted about $25 \%$ of the sittings of the House from $1833-53,1855-58,1861-67$. The numbers given in the last column are not the relevant denominators for the percentages given in the middle column because ten separate ministries were investigated and their percentages averaged.

With Ingram's data in hand, we can ask: Did the probability that a constituency's MP(s) would ask at least one question (in the subperiods searched) increase with the size of the constituency? The answer is indicated in Table I. This table, which deals only with English and Welsh boroughs, first divides such boroughs into five categories of size and then, for each category, displays the percentage of boroughs in that category represented by an MP who asked a question. As can be seen, the percentage increases steadily with size: whereas only I $8 \%$ of the smallest English/Welsh boroughs were represented by MPs who asked questions, $68 \%$ of the largest were so represented, and the figures for the three intermediate sizes are ordered as would be expected. ${ }^{19}$

All told, the cross-sectional evidence is straightforward and consistent. Whether one measures activity by the delivery of speeches in debate, by the casting of votes in divisions, by the introduction of bills, or by the asking of questions, MPs from larger constituencies were on average more active. 


\section{SOME CONSEQUENCES OF BACKBENCH ACTIVITY}

The consequences of increased backbench activity for the legislative agenda deserve some discussion. More MPs trying to legislate on the floor quickly found that the floor afforded only a fixed amount of time. Competition for this scarce commodity took the form of "raids" on the established agenda, wherein a member would use some parliamentary device to seize a bit of time for his own use. Raiding of this type, however, led to a chaotic and unpredictable legislative agenda that profited no one. The result (in combination with other factors) was that the privileges backbenchers used to break into the legislative agenda were one-by-one removed by Standing Order, leaving the government in greater and greater control (Fraser 1960; Cromwell 1967; Cox 1987).

One might ask why backbench MPs were not able to salvage their legislative powers. It is not because private members were particularly shy about asserting their rights. Backbench complaints of lost dignity and power spice parliamentary debates on procedure throughout the century. ${ }^{20}$ So why did the Commons not, for example, adopt a committee system like that of the U.S. Congress?

The question seems apt because of the similarity of procedures in the House of Commons and House of Representatives in $1800 .{ }^{21}$ In both bodies, anyone wishing to legislate had to convince the Committee of the Whole that their legislative aims were valid before they could bring in a bill. After leave to introduce a bill was granted, a select committee was appointed to draw up the bill. This was a general legislative procedure and did not take much advantage of specialization of labor. In both the United States and Britain this eighteenth-century procedure was destroyed by the increasing volume of legislation that the national legislature undertook. In the United States the old procedure was replaced by a system of bipartisan standing committees (Cooper 1970). Each committee specialized in a given area of legislation, thus enabling the House of Representatives to increase the number of problems that it could legislatively address. The response of the House of Commons to similar circumstances was to delegate legislative authority. But in its case, authority was delegated to the various ministers of the crown. Because these ministers all sat in a preexisting body, the cabinet, which was confined to the members of one party only, the resulting system was fundamentally different. 
Why did the British system evolve in the direction of cabinet government while the American went down the road to committee government? This is too large a question to answer fully here, but some main points can be noted.

Probably of most importance is the contrast between American separation of powers and British nonseparation. Cabinet members in the United States were forbidden from holding office in the legislature; those in Britain were not. Officials in both countries would have to administer whatever laws were passed, and it was natural that they should take an interest. But where Alexander Hamilton had to organize his followers in Congress without the benefit of membership, British ministers could take a direct hand in legislative affairs. Moreover, the ability of British cabinet ministers to legislate was not just the ability of any ordinary member. True, the procedures of the House before I83I gave little formal preference to ministers, but an informal preference had been evident since at least $18 \mathrm{I} 2$ (see Cox 1987: 47); ministers, at least by 1830 , also had more resources at their disposal-specialized legislative draftsmen, research staff, and so forth.

This meant that the situations in the House of Representatives and the House of Commons were different when each faced a demand for greater legislative output. The American legislature was filled with institutional equals; there was no preexisting seed from which specialized legislative agents might naturally spring. The British legislature, in contrast, already had a group of membersthe ministers - with clear, if still relatively small, legislative advantages.

This small initial advantage naturally tended to grow. Any MP with legislative goals to pursue had a variety of strategies available. He could attempt to push the bill through the old procedure, competing with many others for a small amount of time; he could seek to force his way into the cabinet and use the advantages that would then accrue to him; he could pressure the existing ministers to take up the bill(s) that he wished passed; or he could attempt to overhaul the entire process by which the legislature operatede.g., by introducing standing committees-and then push his bill through the new procedure. Of these strategies, the last was the least incremental and the least easy. The first was increasingly ineffective. The second took some time. What happened over and over was that ministers were pressured to legislate, which gave 
them an incentive to develop their institutional advantages further, which thus made government support even more vital to secure for the next piece of legislation. The cabinet became the focal point of all legislative pressures; because it was, for the most part, responsive to these pressures and effective in meeting legislative demands, schemes for the introduction of powerful standing committees - or any other institutional rival to the cabinet - met with little success.

\section{CONCLUSION}

This essay has examined the impact of the first, second, and third reform acts on the legislative behavior of British MPs, with particular emphasis on the introduction of bills. The logic of the investigation is simple: more MPs serving mass constituencies should have meant more MPs with electoral incentives to legislate or to appear to legislate, hence more MPs who were active in Parliament. The evidence on the whole is positive. Each reform act was followed by an abrupt increase in legislative activity of one kind or another (speaking in debate, voting in divisions, making motions, introducing bills), if not always of the same kind; moreover, at any given time it was the MPs from the larger constituencies who tended to be the most active.

The broader topic to which this article contributes-the impact of suffrage expansion on legislative activity and structure-potentially leads in many directions. The previous section touched on two of them: the streamlining of legislative procedure, and the regularization of control over the legislative agenda. Although not all efforts to streamline procedure and to regularize the agenda have taken the form that they did in the mother of parliamentswitness the U.S. Congress - the fact of adaptation appears general in those countries in which representative institutions predate mass democracy. In our view, much of the legislative adaptation to mass democracy, in whatever country, can be viewed as an effort to accommodate the electoral interests of incumbent legislators. Indeed, this seems to us as large and valid a theme as the purely electoral one sounded by the classical writers on suffrage expansion (Weber 1946; Duverger 1955). Nonetheless, this opinion must remain speculative because so little is known about the comparative history of legislative procedure. 


\section{NOTES}

I The emphases regarding the last of these developments has usually been on how socialist parties pushed for expansion of the electorate rather than on how expansion of the electorate facilitated the creation and maintenance of socialist parties, but evidence can be found to support both causes.

2 See, for example, C. W. Wynn's comments in Parliamentary Debates, 3rd series, xv, I013. Hereinafter cited as Debates, followed by volume and page number(s).

3 The leaders of the governing and opposition parties in the British House of Commons sit on front-row benches, and hence are referred to as frontbenchers. Their followers, sitting behind them, are backbenchers. A slightly different distinction is between those holding office under the Crown-the "public" or "official" members-and those not holding office under the Crown-the "private" members.

4 In the case of third reform act, the redrawing of district boundaries was done by a separate act.

5 It is true that the percentage of races contested in England declines from I832 to reach twin troughs in $I 847$ and $I 859$ (of $47 \%$ and $49 \%$, respectively) - and that the pattern is similar for the U.K. as a whole. But even these postreform low points are well above the highest figure from I8I230 ( 1818 's $36 \%$ ). Similarly, the highest figure for $1832-67$ is no greater than the lowest figure for $1867-84$. Thus, the averages in this case are in no sense misleading. Not only was each reform act followed by a considerable increase in the percentage of constituencies contested on average, but the variation around the average in each period was small enough that each remains distinct, in the sense that the range of values within each period does not overlap that of any other (or barely does). This is not to deny that the decline after 1832 is important; it is to deny that this decline was large relative to the initial jump from pre-reform to postreform.

6 On the difference between politics in small and large constituencies, see Hanham 1978; Fraser 1976.

7 In practice, we have relied on the membership of the select committee (that was invariably appointed to draw up the bill) in determining whether a bill was a government bill or a private member's bill. If the first-named member of the committee was a public member, then the bill was put in the "government" category, otherwise in the "private members" " category. Early in the century, anywhere from $4 \%$ to $15 \%$ of the bill committees are "mixed"with some government members and some private members. It is only for these that any ambiguity exists about whose bill it is.

8 (I) For data on sessions from I8I3-I4 through I83I, I839 through I845, I850, I854-55, I860, and I865, we used the Commons Journal. We relied on the membership of the select committee in determining whether a bill was a government bill or a private member's bill. In all cases that we checked, the first-named member of the committee was the member who introduced the bill (except that government members sometimes changed positions). (2) For sessions $1836,1847-48,1851,1856$, and I868-69 through I899, we used various of the British Parliamentary Papers: I836 vol, xlvii; 1847- 
48 vol. li; I85 I vol. xlvii; I856 vol. li; I87 I vol. Ivi; 1872 vol. xlvii; I 873 vol. liii; 1874 vol. lii; 1875 vol. $1 x$; 1876 vol. $1 x$; I877 vol. $1 x v i i i ; ~ I 878$ vol. Ixi; I $878-79$ vol. lviii; I880 vol. lvi; I88I vol. Ixxiv; I882 vol. lii; I883 vol. liv; I884 vol. lxii; I884-85 vol. Ixii; I886 vol. lii; I 887 vol. Ixvi; I 888 vol. lxxix; I889 vol. Ix; I89o lvii; I890-9I vol. lxii; I892 vol. Ixiii; I89394 vol. Ixx; I894 vol. Ixviii; I895 vol. Ixxix; I896 vol. Ixvii; I897 vol. 1xxii; I898 vol. Ixxii; I899 vol. Ixxvii. (3) For session 186I, we used the tables given in the Parliamentary Record, I86I, London: T. F. A. Day, I86I . (4) For sessions I864 and I867-68, we used the information given in the indexes to the Debates clxxvi and cxciii.

9 The increasing trend in the number of private members' bills introduced, combined with the stasis in the number of government bills introduced, produced a "reversal" in I 872 ; before this date, the government invariably introduced more bills than did the backbenchers; after this date, the backbenchers introduced more than the government. The number of government bills introduced does not increase, mostly because the size of government bills grows throughout the century. Provisional orders bills are a prime example. The number of private members' bills increases for the reasons we cite. The two trends together produced the reversal in 1872 . Nonetheless, as will be seen, the rising tide of backbench introductions did not lead to a rising tide of backbench enactments.

Io Debates xxxix, 197.

I I The number of amendments on going into Supply also increased, at least if one can judge from the complaints of the government and from the House's attempts-in $1872,1873,1876,1879$, and 1882 - to curtail their use. See Debates ccix, I059; and Redlich 1908, vol. i, II5-32. The number of questions per day also increased, at least after passage of the third reform act. See Ingram 1990.

I2 The first reform act dummy equaled I for all sessions after the first reform act; zero otherwise. The second reform act dummy equaled I for all sessions after the second reform act; it was zero otherwise. The third reform act dummy equaled I for all sessions after the third reform act; otherwise it was zero.

I3 Exactly why there was a two-session lag before the onset of the expected decline in backbench success rates is not entirely clear. One contributing factor is the number of backbench bills introduced: 79 in I869, 83 in I870. Both of these numbers are high, but not unprecedented, by pre-reform standards (for example, there were 82 backbench bills introduced in I86I). A new high is not set until $187 \mathrm{I}$ 's 96 , all but one of the numbers after that being above IOO. So part of the reason for the delay is that the explosion in backbench bills has a similar delay in it. This raises the question of why the increase in the number of backbench bills did not follow the second reform act more immediately. The answer may be two-fold. First, some "learning" may have gone on as those members representing the more populous constituencies discovered the necessity or usefulness of introducing bills (this would presumably be gradual, not abrupt). Second, the ambitious legislative program of the Gladstone ministry in its first two years may have attracted so much attention that the incentive for backbenchers to legislate on their 
own was diminished. Neither of these reasons is entirely satisfactory, but we know of no more likely explanation. In particular, no procedural changes seem to have accounted for the change.

14 The second reform act dummy, however, is significant only in a one-tailed test, not in a two-tailed test.

I5 The numbers reported in the text regarding "government acts" refer to the period after I8I5. The regressions referred to measure "time" by the year of each session: 1814,1815 , and so on.

I6 On the declining importance of private members' bills, and the growing importance of the government's, see, e.g., Lowell I912, vol. i, 314; Debates cxcvii, I 188; Todd 1869, vol. ii, 63; Gurowich 1984, 630 n. 178; Cox 1987; Fraser 1960 .

17 Further evidence can be found in Glynn I949, Table 88.

I 8 We have not calculated the analogous figures for any of the other categories-non-English boroughs, English counties, or non-English counties-in 1856 . Nor have we looked at figures for any other year. The evidence is thus slight, albeit positive. Unfortunately, the data described in the previous section did not include the identity of the MP introducing the bill, so we cannot use those data to study the hypothesis at hand.

I9 A considerable amount of additional evidence showing that larger constituencies were more likely to be represented by MPs who asked questions can be found in Ingram (1990).

20 For some typical examples from the early I870s, see Debates cciv, I82-83, I9I; ccix, I088; ccxiv, 249-50, 253, 256-57; ccxv, 229-30.

21 This was no accident, of course, since the procedure of the American legislature was based primarily on that of the British, either directly or indirectly (via the colonial assemblies).

\section{REFERENCES}

Chester, D. N., and N. Bowring (1962) Questions in Parliament. Oxford: Clarendon Press.

Cooper, J. (I970) "The Origins of the standing committees and the development of the modern House." Rice University Studies 56:I-I67.

Cox, G. W. (1987) The Efficient Secret: The Cabinet and the Development of Political Parties in Victorian England. Cambridge: Cambridge University Press.

Cromwell, V. (1967) "The losing of the initiative by the House of Commons, I780-19I4. Transactions of the Royal Historical Society I8:1-17.

Duverger, M. (1955) Political Parties: Their Organization and Activity in the Modern State, translated by B. North and R. North. London: Methuen.

Fraser, D. (1976) Urban Politics in Victorian England. Leicester: Leicester University Press.

Fraser, P. (1960) "The growth of ministerial control in the nineteenth century House of Commons." English Historical Review 74:444-63.

Gash, N. (1977) Politics in the Age of Peel. Hassocks: Harvester Press.

Glynn, J. K. ( 1949) “The private Member of Parliament, I833-I868." Ph.D. diss., University of London. 
Gurowich, P. M. (1984) "The continuation of war by other means: Party and politics, I855-I865." Historical Journal 27:603-3I.

Hanham, H. J. (1978) Elections and Party Management: Politics in the Time of Disraeli and Gladstone. 2d ed. Hassocks: Harvester Press.

Ilbert, C. (I90I) Legislative Methods and Forms. Oxford: Clarendon Press.

Ingram, J. (1990) "The development of questioning in the British House of Commons." University of California at San Diego. Typescript.

LaPalombara, J., and M. Weiner (eds.) ( 1966) Political Parties and Political Development. Princeton, NJ: Princeton University Press.

Ramm, A. (1984) "The parliamentary context of cabinet government, I868I874." English Historical Review 99:739-69.

Redlich, J. (1908) The Procedure of the House of Commons. 3 vols. London: Archibald Constable.

Richards, P. G. ( I979) "Private Members' legislation," in S. A. Walkland (ed.) The House of Commons in the Twentieth Century. Oxford: Clarendon Press.

Todd, A. ( 1869) On Parliamentary Government in England: Its Origin, Development, and Practical Operations. London: Longman.

Weber, M. (1946) Essays in Sociology, translated and edited by H. H. Gerth and C. W. Mills. New York: Oxford University Press. 